Volume 6, Nomor 1, April 2017

\title{
PENERAPAN STRATEGI ACTIVE LEARNING TIPE QUIZ TEAM \\ UNTUK MENUMBUHKAN KARAKTER RASA INGIN TAHU SISWA \\ DALAM PEMBELAJARAN SEJARAH \\ (Penelitian Siklus Kelas: X MIIA 3 SMA Kartika XIX-1 Bandung)
}

Oleh:

Suhaibah Aslamiyah dan Erlina Wiyanarti ${ }^{1}$

\begin{abstract}
ABSTRAK
Penelitian ini bertujuan untuk menumbuhkan karakter rasa ingin tahu siswa dalam pembelajaran sejarah. Melalui observasi awal, dapat dilihat karakter rasa ingin tahu yang dimiliki siswa kelas X MIIA 3 masih rendah. Terlihat dari tingkat inisiatif/minat siswa dalam proses pembelajaran sejarah, baik dalam kemauan siswa dalam bertanya, kemampuan siswa untuk menjawab pertanyaan ataupun kemampuan siswa untuk berkontribusi dalam kegiatan pembelajaran yang masih belum sesuai dengan yang diharapkan. Penelitian ini mengunakan metode penelitian tindakan kelas (PTK) dengan menggunakan desain penelitian dari Kemmis dan Mc.Taggart yang dilaksanakan dalam empat siklus. Teknik pengumpulan data yang digunakan adalah observasi, wawancara, dan studi dokumentasi. Pada penelitian ini, instrument penelitian yang digunakan adalah pedoman observasi, pedoman wawancara, dan catatan lapangan. Berdasarkan hasil penelitian diketahui bahwa Strategi Active Learning Tipe Quiz Team dapat menumbuhkan karakter rasa ingin tahu siswa kelas X MIIA 3. Tumbuhnya rasa ingin tahu siswa terlihat dari kenaikan presentase rasa ingin tahu siswa dalam setiap siklusnya. Peningkatan rasa ingin tahu siswa tersebut dapat dilihat dari nilai rata-rata pada setiap siklusnya. Berdasarkan data dari hasil penelitian, terlihat bahwa pada tindakan I, perolehan rata-rata adalah (58.53\%). Kemudian pada tindakan II, perolehan rata-rata adalah (65.47\%). Sedangkan pada tindakan III, perolehan rata-rata adalah (71.42\%). Selanjutnya pada tindakan IV, perolehan rata-rata adalah $(71.03 \%)$. Dapat terlihat berdasarkan dari hasil pengolahan data tersebut, menunjukan bahwa karakter rasa ingin tahu siswa kelas X MIIA 3 SMA Kartika XIX-1 Bandung mengalami peningkatan setelah di terapkannya strategi active learning tipe quiz team dalam pembelajaran sejarah di kelas.

Kata kunci: Karakter rasa ingin tahu, strategi active learning tipe quiz team, penelitian tindakan kelas, pembelajaran sejarah.
\end{abstract}

\footnotetext{
${ }^{1}$ Penulis adalah Mahasiswa Pendidikan Sejarah, Fakultas Pendidikan Ilmu Pengetahuan Sosial, Universitas Pendidikan Indonesia, Erlina Wiyanarti sebagai Pembimbing I dan Yeni Kurniawati sebagai Pembimbing II. Penulis dapat dihubungi melalui nomor 081807311019 atau email miasuhaibah@yahoo.com
} 


\begin{abstract}
This research aims to increasing the student's curiousity character in learning history. Through the observation, it can be noticeable that curiousity character in $X$ MIIA 3 is on minimum level. The curiousity character can be seen by the level of student's initiative or interest toward the process of learning history, such as in asking question, answering the question, or student's capability to contribute on learning activity. This research used Classroom Action Research (CAR) by using design research that invented by Kemmis and Mc.Taggart which realized by four cycles. The researcher use many technique of collecting data such as observation, interview, and study documentation. This research also used the research instrument such as observation instrument, interview instrument, and field data. Based on the final result can be revealed that Active Learning Tipe Quize Team strategy can increase the student's curiosity character in X MIIA 3. The development of curiosity increased in every cycle and it can be countable by the average of value in every single cycle. Based on the data, it can be described that in action I, the average of value is (58.53\%). In action II, the achievement is (71.42\%). Then in action III, the data average got (71.42\%). And in action IV, the data average is $(71.03 \%)$. all of data shows that student's curious character in X MIIA 3 SMA Kartika XIX-1 Bandung increased after the researcher applied the active learning tipe quiz team strategy in history class.
\end{abstract}

Keywords: active learning, classroom research action, curious character, learning history, tipe quiz team strategy.

\section{PENDAHULUAN}

Pendidikan diyakini banyak orang sebagai proses yang dinamis dalam melahirkan kemampuan manusia, bahkan sering dianggap sebagai suatu proses memanusiakan manusia. Oleh karena itu, pendidikan bagi setiap orang begitu penting dan merupakan suatu keharusan. Proses ini sejatinya dilakukan sepanjang hayat manusia. Namun secara formal, proses pendidikan ini diaplikasikan dalam kegiatan pembelajaran di sekolah.
Sejalan dengan itu untuk mewujudkan pembelajaran yang bisa memanusiakan manusia negara merancang pendidikan yang didasarkan pada pendidikan karakter. Dalam Barnawi dan Arifin (2012, hlm. 45) ada beberapa Undangundang yang digunakan sebagai landasan pelaksanaan pendidikan karakter di Indonesia. Pertama, dalam Undang-Undang No. 20 Tahun 2003 tentang Sistem Pendidikan Nasional, fungsi dan tujuan pendidikan nasional dalam Bab 2 Pasal 3 yang tercantum sebagai berikut: 
Pendidikan nasional berfungsi mengembangkan kemampuan dan membentuk watak serta peradaban bangsa yang bermartabat dalam rangka mencerdaskan kehidupan bangsa, bertujuan untuk berkembangnya potensi siswa agar menjadi manusia yang beriman dan bertakwa kepada Tuhan Yang Maha Esa, berakhlak mulia, sehat, berilmu, cakap, kreatif, mandiri, dan menjadi warga negara yang demokratis serta bertangung jawab (hlm.45).

Kedua, dalam Undang-Undang RI No. 17 Tahun 2007 tentang RPJPN (Rencana Pembangunan Jangka Panjang Nasional), dinyatakan tujuan pembangunan jangka panjang tahun 2005-2025 adalah mewujudkan bangsa yang maju, mandiri, dan adil sebagai landasan bagi tahap pembangunan berikutnya menuju masyarakat yang adil dan makmur berdasarkan Pancasila dan UndangUndang Dasar Negara Republik Indonesia Tahun 1945. Pencapaian tersebut ditandai hal-hal berikut:

a. Terwujudnya karakter bangsa yang tangguh, kompetitif, berakhlak mulia, dan bermoral berdasarkan falsafah Pancasila.

b. Makin mantapnya budaya bangsa yang tercermin dalam meningkatkanya peradaban, harkat, dan martabat manusia Indonesia dan menguatnya jati diri dan kepribadian bangsa.

Sejalan dengan tujuan UndangUndang tersebut, Mulyasa (2014, hlm. 58) mengungkapkan bahwa Kurikulum 2013 juga menekankan pada pengembangan berbagai potensi siswa secara optimal, terutama dalam kaitanya dengan pengembangan karakter, akhlak dan moral siswa. Dalam hal ini, Mendikbud (dalam Mulyasa, 2014, hlm. 58) mengungkapkan tiga hal yang tidak boleh lepas dari Kurikulum 2013, yakni pengembangan skill, attitude, dan knowledge. Lebih lanjut dikatakan bahwa desain Kurikulum 2013 tidak hanya menekankan pada aspek ilmiah saja. Justru kurikulum baru ini akan lebih kaya dengan nilainilai seni dan moral. Hal ini penting menurut Gardner (dalam Mulyasa, 2014, hlm. 58) karena "there is no excellent performance without high morale. No morale, no excellence. Excellenced can be experienced at ever level and in every serious kind of education". 
Kementrian

Pendidikan

Nasional (Kemendiknas) telah merumuskan delapan belas nilai karakter yang akan ditanamkan dalam diri siswa sebagai upaya membangun karakter bangsa, dari ke delapan belas karakter bagsa salah satunya karakter rasa ingin tahu. Rasa ingin tahu adalah cara berfikir, sikap dan perilaku yang mencerminkan penasaran dan keingintahuan terhadap segala hal yang dilihat, didengar, dan dipelajari secara mendalam (Suyadi, 2013, hlm. 7). Selain itu Hasan (2008) mengungkapkan bahwa pembelajaran sejarah berpotensi untuk:
a. Mengembangkan kemampuan berfikir;
b. Mengembangkan rasa ingin tahu;
c. Mengembangkan kemampuan berfikir kreatif;
d. Sikap kepahlawanan dan kepemimpinan;
e. Membangun dan mengembangkan semangat kebangsaan;
f. Mengembangkan kepedulian sosial;
g. Mengembangkan kemampuan berkomunikasi;
h. Mengembangkan kemampuan mengelola mencari, mengkomunikasikan informasi (hlm. 3)

Pada dasarnya rasa ingin tahu siswa dapat dikembangkan sesuai dengan pendapat Hellen G. Douglas (dalam Samani dan Hariyanto, 2011, hlm. 134) bahwa "Character isn't inherited, one builds its daily by the way one thinks and act, thought by thought, action by action”. Karakter tidak bisa diwariskan, tetapi sesuatu yang dibangun secara berkesinambungan hari demi hari melalui pikiran dan perbuatan, dan siklus demi siklus. Begitupun karakter rasa ingin tahu yang harus dibangun dan dikembangkan secara berkesinambungan.

Untuk menumbuhkan rasa ingin tahu siswa peneliti menggunakan strategi active learning tipe quiz team untuk menumbuhkan karakter rasa ingin tahu siswa. Dalvi (dalam Hadiansyah, 2015, hlm. 38) mengungkapkan bahwa "Quiz team dapat menghidupkan suasana dan mengaktifkan siswa untuk bertanya ataupun menjawab". Melalui quiz team yang bisa menghidupkan suasana belajar seperti bermain meskipun dalam suasana kompetisi menjadikan siswa senang sehingga tumbuh aktivitas untuk belajar. Di dalam quiz team ini peneliti membuat 
pertanyaan dan peneliti juga mewajibkan setiap kelompok membuat pertanyaan untuk quiz yang akan dilaksanakan di kelas. Dengan quiz team ini secara tidak langsung siswa didorong untuk mencari tahu jawaban dari pertanyaan-petanyaan yang dibuat guru dan kelompok yang nantinya diharapkan oleh peneliti bisa menumbuhkan karakter rasa ingin tahu siswa dalam pembelajaran sejarah.

Indikator dari karakter rasa ingin tahu dalam diri siswa menurut Kemendiknas (dalam Sahlah dan Teguh, 2012) dapat dilihat sebagai berikut :

a. Bertanya kepada guru dan teman tentang materi pelajaran.

b. Membaca sumber di luar buku teks tentang materi yang terkait dengan pembelajaran.

c. Bertanya tentang sesuatu yang terkait dengan materi pembelajaran tetapi di luar yang dibahas di kelas (hlm. 195).

Sedangkan menurut Suningsih (dalam Nurani, 2015) aspek- aspek yang dapat menumbuhkan rasa ingin tahu siswa dapat dilihat sebagai berikut : a. Bertanya

Bertanya merupakan kegiatan atau siklus yang dilakukan seseorang kepada orang lain untuk mendapatkan informasi sesuai dengan yang dikehendaki. Bertanya merupakan salah satu aspek yang dapat mengembangkan rasa ingin tahu siswa.

b. Menjawab Pertanyaan yang Muncul dalam Proses Pembelajaran

Selain bertanya, kemampuan siswa dalam menjawab pertanyaanpun menjadi aspek yang dapat mengembangkan rasa ingin tahu siswa. Guru harus mampu menciptakan suasana pembelajaran yang luwes dan menarik sehingga siswa memiliki keinginan dan keberanian untuk menjawab pertanyaan yang muncul dalam proses pembelajaran, baik pertanyaan yang berasal dari guru, maupun siswa.

c. Keterampilan Merespon

Keterampilan merespon atau responsif merupakan sikap seseorang, dalam hal ini siswa yang menunjukan sikap interaktif, memiliki keterampilan mendengarkan, dan juga menunjukan sopan santun dalam berbahasa dan bersikap.

d. Memiliki Inisiatif dan Antusias

Inisiatif adalah pemeikiran seseorang yang disertai dengan siklus untuk melakukan sesuatu atau tanpa ada perintah dari orang lain. Sedangkan antusias merupakan sikap seseorang 
yang menunjukan semangat dalam melakukan sesuatu. Kedua aspek ini saling mendukung satu sama lain (hlm. 21-22).

Berdasarkan pendapat di atas, peneliti menyimpulkan adanya karakter rasa ingin tahu dalam diri siswa dapat terlihat dari adanya perasaan antusias dan inisiatif ketika proses pembelajaran berlangsung. Hal tersebut dapat terlihat dari, kemampuan siswa dalam bertanya, membaca dan merespon serta kemampuan menjawab pertanyaan yang muncul dalam proses pembelajaran.

Menurut Hasan (2012, hlm. 87) Mata pelajaran Sejarah memiliki arti strategis dalam pembentukan watak dan peradaban bangsa yang bermartabat serta dalam pembentukan manusia Indonesia yang memiliki rasa kebangsaan dan cinta tanah air. Materi pendidikan sejarah mampu mengembangkan potensi siswa untuk mengenal nilai-nilai bangsa yang diperjuangkan pada masa lalu, dipertahankan untuk kehidupan masa kini, dan dikembangkan lebih lanjut untuk kehidupan masa depan. Bangsa Indonesia masa kini beserta seluruh nilai dan kehidupan yang terjadi adalah hasil perjuangan bangsa pada masa lalu dan akan menjadi modal untuk perjuangan kehidupan pada masa mendatang.

Materi sejarah memberikan informasi mengenai keberhasilan dan kegagalan bangsa dalam menjawab tantangan zaman sehingga menjadi milik bangsa masa kini. Siklus apa yang dilakukan para pelaku sejarah yang tidak berhasil mencapai tujuan dan perbuatan apa yang mereka lakukan yang berhasil mencapai tujuan. Materi yang tercantum dalam cerita sejarah bukan hanya cerita sukses tetapi juga cerita kegagalan. Keberhasilan dan kegagalan adalah hal yang terjadi dalam kehidupan nyata manusia. Kedua sisi kehidupan itu, keberhasilan dan kegagalan, menjadi pelajaran penting. Dengan sifat materi yang demikian, dalam mengembangkan pendidikan karakter, materi pendidikan sejarah mampu mengembangkan fungsi pendidikan sejarah sebagai "bank of examples for solving present problems and chartering future action" Wineburg (dalam Hasan, 2012, hlm. 87). Dalam fungsi ini materi pendidikan sejarah harus mampu mengembangkan 
memori kolektif sebagai bangsa kepada diri siswa.

Pendidikan sejarah memiliki kedudukan yang penting dalam mengembangkan pendidikan karakter dalam diri siswa. Sebagaimana yang dikemukakan oleh Hasan (2008, hlm. 3) yang menyatakan bahwa sesungguhnya pendidikan sejarah mempunyai potensi-potensi yang dapat dikembangkan guna membangun karakter bangsa. Potensipotensi tersebut sebagai berikut:

a. Mengembangkan kemampuan berpikir.

b. Mengembangkan rasa ingin tahu.

c. Mengembangkan kemampuan berpikir kreatif.

d. Mengembangkan sikap kepahlawanan dan kepemimpinan.

e. Membangun dan mengembangkan semangat kebangsaan.

f. Mengembangkan kepedulian sosial.

g. Mengembangkan kemampuan berkomunikasi.

h. Mengembangkan kemampuan mencari, mengolah dan mengkomunikasikan

informasi.

Salah satu potensi yang dapat dikembangkan dalam pembelajaran sejarah ialah karakter rasa ingin tahu, siswa dapat belajar mengenai makna dari nilai-nilai yang terkandung dalam mata pelajaran sejarah, yang berguna sebagai bahan pembelajaran dan media refleksi bagi siswa.

Lawson (dalam Sanjaya, 2008, hlm. 210) menjelaskan bahwa "strategi dapat diartikan sebagai prosedur mental yang berisi tatanan langkah yang menggunakan upaya ranah ciptta untuk mencapai tujuan tertentu". Sedangkan dalam konteks pembelajaran, strategi dapat diartikan sebagai pola-pola umum kegiatan guru, siswa dalam perwujudan kegiatan belajar mengajar untuk mencapai tujuan yang telah digariskan (Djamarah, 2006, hlm. 5). Strategi merupakan salah satu faktor yang dapat mendukung berhasilnya suatu kegiatan pembelajaran, karena arah dari semua keputusan penyusunan strategi adalah pencapaian tujuan. Sementara itu, Kemp (dalam Zubaedi, 2012, hlm. 188) mengemukakan bahwa strategi pembelajaran adalah suatu kegiatan 
pembelajaran yang harus dikerjakan guru dan siswa agar tujuan pembelajaran dapat dicapai secata efektif dan efisien.

Strategi pembelajaran sifatnya masih konseptual dan untuk mengimplementasikannya digunakan berbagai metode pembelajaran tertentu. Dengan kata lain, strategi merupakan "a plan of operation achieving something" sedangkan metode "a way in achieving something". Selanjutnya J.R David dan Sanjaya (dalam Zubaedi, 2012, hlm. 188) menyebutkan bahwa dalam strategi pembelajaran terkandung makna perencanaan. Artinya, bahwa strategi pada dasarnya masih bersifat konseptual tentang keputusan yang akan diambil dalam suatu pelaksanaan pembelajaran. Sanjaya (dalam Komalasari, 2011, hlm. 56) terdapat beberapa metode pembelajaran yang dapat digunakan untuk mengimplementasikan strategi pembelajaran, diantaranya; ceramah, demonstrasi, diskusi, simulasi, laboratorium pengalaman lapangan, brainstorming, debat, simposium, dan sebagainya.

Strategi mengajar pada dasarnya merupakan siklus nyata dari guru melaksanakan pengajaran melalui cara tertentu yang dinilai lebih efektif dan efisien. Dengan kata lain, strategi belajar adalah cara-cara yang akan digunakan oleh pengajar untuk memilih kegiatan belajar yang akan digunakan dalam proses pembelajaran. Pemilihan tesebut dilakukan dengan mempertimbangkan situasi, kondisi, sumber belajar, kebutuhan dan karakteristik siswa yang dihadapi dalam rangka mencapai tujuan pembelajaran yang ditetapkan. Sejalan dengan pendapat di atas Sudjana (dalam Rohani, 2004, hlm. 34) mengatakan bahwa strategi pengajaran (mengajar) adalah "taktik" yang digunakan guru dalam melaksanakan proses belajar mengajar (pengajaran) agar dapat mempengaruhi siswa mencapai tujuan pengajaran secara lebih efektif dan efisien.

Tujuan pembelajaran tidak hanya menekankan kepada akumulasi pengetahuan materi pelajaran, tetapi yang diutamakan adalah kemampuan siswa untuk memperoleh pengetahuan sendiri (self regulated). Karena itu, pembelajaran memerlukan keterlibatan mental dan kerja siswa sendiri. Penjelasan dan pemeragaan 
semata tidak akan menghasilkan self regulated. Yang bisa menghasilkan self regulated adalah pembelajaran aktif (Margana dalam Permana, 2015, hlm. 13). Pendapat tesebut sejalan dengan Hamdani (2011, hlm. 49) yang mengatakan bahwa strategi Active Learning adalah salah satu cara atau strategi belajar mengajar yang menuntut keaktifan serta partisipasi siswa dalam setiap kegiatan belajar seoptimal mungkin sehingga siswa mampu mengubah tingkah lakunya secara efektif dan efisien.

Pembelajaran Aktif (Active Learning) menurut Warsono dan Hariyanto (2012, hlm. 39) dimaksudkan untuk mengoptimalkan pengunaan semua potensi yang dimiliki oleh siswa, sehingga semua siswa dapat mencapai hasil belajar yang memuaskan sesuai dengan karakteristik pribadi yang mereka miliki. Rosalia (2005) menyatakan keaktifan siswa selama proses belajar mengajar sebagaimana tertuang dalam ungkapan berikut :

Salah satu indikator adanya keinginan atau motivasi siswa untuk belajar. Siswa dikatakan memiliki keaktifan apabila ditemukan ciri-ciri perilaku seperti; sering bertanya kepada guru atau siswa lain, mau mengerjakan tugas yang diberikan guru, mampu menjawab pertanyaan, senang diberi tugas belajar, dan lain sebagainya (hlm.4).

Selain itu pembelajaran aktif juga dimaksudkan untuk menjaga perhatian siswa agar tetap tertuju pada proses pembelajaran. Beberapa peneliti membuktikan bahwa perhatian siswa berkurang bersamaan dengan berlalunya waktu. Penelitian Polio (dalam Warsono dan Hariyanto, dkk, 2012, hlm. 39) menunjukan bahwa siswa dalam ruang kelas hanya memperhatikan pelajaran sekitar 40\% dari waktu pembelajaran yang tesedia. Sementara penelitian McKeachie (1986) menyebutkan bahwa dalam sepuluh menit pertama perhatian siswa dapat mencapai $70 \%$ dan berkurang sampai 20\% pada waktu 20 menit berakhir.

Kondisi di atas menunjukan kondisi umum yang sering terjadi di lingkungan sekolah. Hal ini menyebabkan seringnya terjadi kegagalan dalam dunia pendidikan, terutama disebabkan oleh siswa ketika di ruang kelas lebih banyak mengunakan indera-indera pendengaran dibanding visualnya, sehingga apa yang dipelajari di kelas 
cenderung mudah untuk dilupakan.

yang membosankan bagi mereka. Sebagaimana yang Konfusius Dengan memberikan strategi ungkapkan (dalam Silberman, 2013, hlm .1) bahwa; "Apa yang aku dengar, aku lupa. Apa yang aku lihat, aku ingat. Apa yang aku lakukan, aku pahami”.

Ketiga pernyataan ini menekankan pada pentingnya belajar aktif agar apa yang dipelajari siswa tidak menjadi suatu hal yang sia-sia. Silberman (2013, hal. 1) memodifikasi dan memperluas katakata bijak dari Konfusius itu menjadi sesuatu yang disebut pembelajaran aktif. Silberman mengungkapkan sebagai berikut :

Apa yang aku dengar, aku lupa. Apa yang aku dengar dan lihat, aku mengigatnya sedikit. Apa yang aku dengar, lakukan dan tanyakan kepada atau diskusikan dengan orang lain, aku mulai memahaminya. Apa yang aku dengar, lihat, diskusikan, dan lakukan, memberiku pengetahuan dan keterampilan. Apa yang aku ajarkan kepada orang lain, aku menguasainya (hlm.1).

Belajar aktif pada dasarnya berusaha untuk memperkuat dan memperlancar stimulasi dan respon siswa dalam pembelajaran. Sehingga proses pembelajaran menjadi hal yang menyenangkan, tidak menjadi hal

pembelajaran aktif pada siswa dapat membantu ingatan (memory) mereka, sehinga mereka dapat mencapai tujuan pembelajaran dengan sukses. Hal ini kurang diperhatikan dalam pembelajaran konvensional.

Salah satu upaya untuk membangkitkan siswa belajar aktif pada mata pelajaran yaitu dengan pengunaan tipe belajar aktif tipe quiz. team. Dalvi (dalam Hadiansyah, 2015, hlm. 38) menyatakan bahwa "quiz team dapat menghidupkan suasana dan mengaktifkan siswa untuk bertanya ataupun menjawab".

Menurut Silberman (2013, hlm. 149) quiz team merupakan "strategi pembelajaran yang dapat meningkatkan tangung jawab belajar siswa dalam suasana yang menyenangkan". Tipe quiz team ini diawali dengan menerangkan materi pelajaran secara klasikal, lalu siswa dibagi kedalam kelompok besar. Semua anggota kelompok bersamasama mempelajari materi yang sama. Mereka mendiskusikan materi tersebut, saling memberi arahan, saling memberi pertanyaan dan menjawab untuk memahami materi. 
Setelah selesai materi guru memulai quiz team dengan pertanyaan yang di kemas dalam pertandingan akademis. Dengan adanya pertandingan akademis ini maka terjadilah kompetisi antar kelompok, para siswa senantiasa berusaha belajar dengan motivasi yang tinggi disertai rasa ingin tahu yang tinggi pula dalam kompetisi.

\section{Silberman}

mengungkapkan langkah-langkah pembelajaran dengan mengunakan tipe quiz team sebagai berikut:

a. Guru memilih topik yang bisa disajikan dalam tiga segmen.

b. Siswa dibagi dalam tiga kelompok.

c. Guru menjelaskan skenario pembelajaran.

d. Guru menyajikan materi pembelajaran.

e. Guru meminta tim A memberikan kuis kepada tim B. Jika tim B tidak dapat menjawab pertanyaan, tim $\mathrm{C}$ segera menjawabnya.

f. Tim A mengarahkan pertanyaan berikut kepada anggota tim $\mathrm{C}$, dan mengulang proses tersebut.

g. Ketika prosesnya selesai, selanjutnya segmen kedua dari pelajaran dan mintalah tim B sebagai pembuat kuis.

h. Setelah tim B menyelesaikan kuisnya, lanjutkan dengan segmen ketiga dari pelajaran dan tunjuklah tim $\mathrm{C}$ sebagai pemandu kuis (hlm. 135).

Sedangkan menurut Marno dan Idris (2012) langkah-langkah pembelajaran tipe quiz team sebagai berikut:

a. Pilihlah topik yang dapat disampaikan dalam tiga segmen.

b. Bagi siswa menjadi 3 kelompok.

c. Jelaskan format sesi yang akan disampaikan dan mulailah penyampaian materi. Batasi hingga 10 menit.

d. Mintalah tim A untuk membuat kuis jawaban ringkas. Sementara tim B dan $\mathrm{C}$ mereview catatan mereka.

e. Tim A memberi pertanyaan pada tim B. Apabila tidak bisa, pertanyaan pindah ke tim C.

f. Tim A mengajukan pertanyaan ke tim C. Apabila tidak bisa, pertanyaan pindah ke tim B.

g. Lanjutkan penyampaian materi segmen kedua dan tunjuk tim B sebagai pemamdu kuis.

h. Setelah tim B selesai, lanjutkan penyampaian materi dan tim $\mathrm{C}$ sebagai pemandu kuis (hlm. 156160).

Pada penelitian yang akan dilakukan, peneliti memadukan kedua langkah-langkah

pembelajaran 
dengan mengacu pada kedua langkahlangkah di atas. Alasan peneliti memadukan kedua langkah-langkah pembelajaran tersebut agar bisa menyesuaikan dengan kondisi belajar siswa dan tujuan dari penelitian yang dilakukan yaitu menumbuhkan karakter rasa ingin tahu siswa.

\section{METODE PENELITIAN}

Desain penelitian siklus kelas yang akan digunakan dalam penelitian ini adalah desain yang dikembangkan oleh Kemmis dan Mc. Taggart yang di dalamnya memuat komponen yang sesuai dengan penelitian, dalam desain yang dikembangkan oleh Kemmis dan Mc. Taggart setiap siklusnya terdiri atas satu siklus, hal tersebut sesuai dengan solusi yang akan dikembangkan sebagai pemecahan masalah dalam penelitian. Sehingga diharapkan dapat mempermudah penelitian yang akan dilakukan. Dalam desain penelitian Kemmis dan Mc. Taggart apabila di perhatikan dalam suatu sistem spiral atau dalam bentuk pengkajian berdaur siklus dalam satu perangkatnya terdiri dari empat tahap yaitu perencanaan (palnning), pelaksanaan siklus (action), pengamatan (observation), dan refleksi (reflect). Sesudah satu siklus selesai dilaksanakan, kemudian diikuti dengan adanya perencanaan ulang yang dilaksanakan dalam bentuk siklus tersendiri. Demikian seterusnya, atau dengan beberapa kali siklus.

1. Perencanaan, dalam perencanaan ini peneliti menyiapkan komponen pembelajaran yang akan digunakan dalam pembelajaran seperti RPP, lembar observasi, powerpoint, membuat pertanyaan quiz team babak pertama dan babak ketiga yang akan dilaksanakan dalam tiga babak, dan nomor siswa.

2. Pelaksanaan, dalam pelaksanaan peneliti terlebih dahulu membagi nomor (name take) sesuai nomer absen untuk mempermudah observer. Selanjutnya peneliti membagi siswa kedalam lima kelompok setelah membagi kelompok peneliti menyampaikan materi selama lima belas menit, setelah penyampaian materi selesai setiap 
kelompok diminta untuk

membuat tiga pertanyaan

untuk quiz team babak kedua

selama lima menit setelah itu

peneliti memulai quiz team

yang terbagi dalam tiga

babak. Babak pertama

dimulai dengan pertanyaan

dari guru dan dimulai dari

kelompok pertama dan

seterusnya, babak kedua

dimulai dengan pertanyaan

yang dibuat oleh setiap

kelompok dan dimulai dari

kelompok pertama dan

seterusnya. Babak ketiga

dimulai dengan pertanyaan

dari guru kembali dan

dimulai dari kelompok

pertama dan seterusnya.

3. Pengamatan, pengamatan dilaksanakan pada saat siklus dilakukan dengan bantuan dua orang observer yang mengamati karakter rasa ingin tahu siswa pada saat siklus strategi active learning tipe quiz team berlangsung.

4. Refleksi, refleksi dilakukan setelah pelaksanaan dan observasi dilakukan. Refleksi bertujuan untuk mengetahui hal-hal apa saja yang kurang atau belum berhasil dilaksanakan dengan baik dalam pelaksanaan siklus pada siklus sebelumnya serta mengidentifikasi faktorfaktor yang mempengaruhi pelaksanaan siklus untuk kemudian dilakukan perbaikan pada siklus selanjutnya.

\section{HASIL PENELITIAN DAN PEMBAHASAN}

Hasil observasi dari setiap indikator karakter rasa ingin tahu siswa dari siklus I-IV dapat dilihat pada tabel berikut. 
Tabel.1

Hasil Indikator Karakter Rasa Ingin Tahu siswa pada siklus I-IV

\begin{tabular}{|c|c|c|c|c|c|c|}
\hline \multirow{2}{*}{ No } & \multirow{2}{*}{$\begin{array}{l}\text { Indikator } \\
\text { Rasa Ingin } \\
\text { Tahu }\end{array}$} & \multirow{2}{*}{$\begin{array}{l}\text { Sub-indikator } \\
\text { Rasa Ingin Tahu }\end{array}$} & \multicolumn{4}{|c|}{ Rata-rata Siklus \% } \\
\hline & & & $\begin{array}{l}\text { Siklus } \\
\text { I }\end{array}$ & $\begin{array}{c}\text { Siklus } \\
\text { II }\end{array}$ & $\begin{array}{l}\text { Siklus } \\
\text { III }\end{array}$ & $\begin{array}{c}\text { Siklus } \\
\text { IV }\end{array}$ \\
\hline \multirow{3}{*}{1} & \multirow{3}{*}{ Bertanya } & $\begin{array}{l}\text { Siswa dengan antusias dapat membuat } \\
\text { pertanyaan melalui diskusi kelompok }\end{array}$ & \multirow{3}{*}{11.90} & \multirow{3}{*}{14.63} & \multirow{3}{*}{31.70} & \multirow{3}{*}{24.39} \\
\hline & & $\begin{array}{l}\text { Siswa dapat bertanya dengan antusias } \\
\text { kepada guru dan teman terkait dengan } \\
\text { materi }\end{array}$ & & & & \\
\hline & & $\begin{array}{l}\text { Siswa dengan antusias bertanya diluar } \\
\text { konteks yang dijelaskan oleh guru }\end{array}$ & & & & \\
\hline \multirow{3}{*}{2} & \multirow{3}{*}{ Menjawab } & $\begin{array}{l}\text { Siswa cepat tanggap ketika diberi } \\
\text { pertanyaan/mengacungkan tangan }\end{array}$ & \multirow{3}{*}{23.80} & \multirow{3}{*}{29.26} & \multirow{3}{*}{48.78} & \multirow{3}{*}{53.65} \\
\hline & & $\begin{array}{l}\text { Siswa dapat menjawab dengan lancar } \\
\text { dan benar }\end{array}$ & & & & \\
\hline & & $\begin{array}{l}\text { Siswa dapat menjawab/menambahkan } \\
\text { materi atau informasi yang dijelaskan } \\
\text { oleh guru dengan antusias }\end{array}$ & & & & \\
\hline \multirow{3}{*}{3} & \multirow{3}{*}{ Buku } & $\begin{array}{l}\text { Siswa dengan senang hati } \\
\text { membuka/membaca buku paket } \\
\text { pelajaran sejarah terkait materi yang } \\
\text { sedang dipelajari }\end{array}$ & \multirow{3}{*}{2.38} & \multirow{3}{*}{9.75} & \multirow{3}{*}{12.19} & \multirow{3}{*}{12.19} \\
\hline & & $\begin{array}{l}\text { Siswa dengan senang hati memembaca } \\
\text { buku yang direkomendasikan oleh guru } \\
\text { terkait materi yang sedang dipelajari. }\end{array}$ & & & & \\
\hline & & $\begin{array}{l}\text { Siswa dengan senang hati membaca } \\
\text { buku lain selain buku paket sejarah yang } \\
\text { diberikan sekolah dan yang } \\
\text { direkomenasikan guru }\end{array}$ & & & & \\
\hline \multirow{3}{*}{4} & \multirow{3}{*}{ Internet } & $\begin{array}{l}\text { Siswa mencari/membaca dari internet } \\
\text { dengan sunguh-sunguh terkait pelajaran } \\
\text { sejarah yang sedang dipelajari }\end{array}$ & \multirow{3}{*}{23.80} & \multirow{3}{*}{43.90} & \multirow{3}{*}{56.09} & \multirow{3}{*}{51.21} \\
\hline & & $\begin{array}{l}\text { Siswa mencari/membaca dari internet } \\
\text { dengan sunguh-sunguh yang } \\
\text { direkomendasikan oleh guru terkait } \\
\text { materi yang sedang dipelajari. }\end{array}$ & & & & \\
\hline & & $\begin{array}{l}\text { Siswa mencari/membaca dari internet } \\
\text { lain selain yang direkomendasikan oleh } \\
\text { guru dengan sunguh-sunguh. }\end{array}$ & & & & \\
\hline
\end{tabular}

Berdasarkan hasil observasi, indikator menjawab dan membuka setiap indikator rasa ingin tahu jika sumber internet. Dapat dilihat dua dilihat dari tabel di atas menggalami indikator menjawab dan membuka kenaikan yang signifikan. Kenaikan indikator tersebut yang paling sumber internet ini dari silkus I-IV signifikan di setiap siklusnya adalah mencapai $50 \%$ dari jumlah siswa yang hadir dalam setiap siklusnya 


\section{FACTUM}

Volume 6, Nomor 1, April 2017

Tabel. 2

Perolehan Skor Karakter Rasa Ingin Tahu Siaswa dengan Mengunakan Strategi Active Learning Tipe Quiz Team Pada siklus I-IV

\begin{tabular}{|c|c|c|c|c|c|}
\hline \multirow[b]{2}{*}{ No } & \multirow[b]{2}{*}{ Inisial Nama Siswa } & \multicolumn{4}{|c|}{ Perolehan Skor } \\
\hline & & Siklus I & Siklus II & Siklus III & $\begin{array}{c}\text { Siklus } \\
\text { IV }\end{array}$ \\
\hline 1 & $\mathrm{AD}$ & 4 & 6 & 7 & 8 \\
\hline 2 & AMR & 9 & 10 & 10 & 10 \\
\hline 3 & $\mathrm{ABF}$ & 10 & 11 & 12 & 11 \\
\hline 4 & $\mathrm{~A}$ & 4 & 9 & 9 & 9 \\
\hline 5 & $\mathrm{AP}$ & 5 & 7 & 7 & 7 \\
\hline 6 & DBS & 9 & 9 & 9 & 9 \\
\hline 7 & DNL & 5 & 9 & 10 & 9 \\
\hline 8 & ER & 6 & 6 & 6 & 6 \\
\hline 9 & FAZ & 7 & 9 & 9 & 9 \\
\hline 10 & FR & 5 & 7 & 9 & 9 \\
\hline 11 & FAA & 4 & 6 & 7 & 7 \\
\hline 12 & GG & 9 & 5 & 5 & 7 \\
\hline 13 & GI & 9 & 9 & 9 & 9 \\
\hline 14 & GRR & 6 & 6 & 6 & 6 \\
\hline 15 & GAF & 6 & 9 & 9 & 9 \\
\hline 16 & $\mathrm{I}$ & 7 & 6 & 8 & 8 \\
\hline 17 & KK & 9 & 9 & 10 & 10 \\
\hline 18 & MIS & 9 & 9 & 9 & 9 \\
\hline 19 & MAR & 7 & 10 & 9 & 9 \\
\hline 20 & MNF & 6 & 7 & 7 & 7 \\
\hline 21 & MAW & 9 & 9 & 10 & 10 \\
\hline 22 & MAS & 9 & 9 & 9 & 9 \\
\hline 23 & M. RK & 10 & 10 & 10 & 10 \\
\hline 24 & NRK & 5 & 9 & 9 & 9 \\
\hline 25 & $\mathrm{NN}$ & 9 & 9 & 10 & 10 \\
\hline 26 & PW & 6 & & & \\
\hline 27 & $\mathrm{RR}$ & 6 & 6 & 8 & 8 \\
\hline 28 & $\mathrm{RI}$ & 10 & 10 & 10 & 10 \\
\hline 29 & RWA & 9 & 9 & 10 & 9 \\
\hline 30 & $\mathrm{RD}$ & 4 & 9 & 10 & 10 \\
\hline 31 & RUA & 4 & 9 & 10 & 10 \\
\hline 32 & $\mathrm{RG}$ & 7 & 7 & 8 & 8 \\
\hline
\end{tabular}




\begin{tabular}{|c|c|c|c|c|c|}
\hline 33 & RDN & 10 & 10 & 10 & 9 \\
\hline 34 & $\mathrm{RR}$ & 6 & 9 & 10 & 9 \\
\hline 35 & SRSM & 5 & 4 & 8 & 8 \\
\hline 36 & SAA & 10 & 9 & 10 & 10 \\
\hline 37 & SNF & 6 & 9 & 9 & 9 \\
\hline 38 & SFA & 5 & 5 & 7 & 7 \\
\hline 39 & $\mathrm{SNH}$ & 10 & 10 & 11 & 11 \\
\hline 40 & TAR & 6 & 6 & 8 & 8 \\
\hline 41 & WSR & 4 & 4 & 7 & 7 \\
\hline 42 & YS & 9 & 9 & 9 & 9 \\
\hline \multicolumn{2}{|c|}{ Jumlah Skor } & 295 & 330 & 360 & 358 \\
\hline \multicolumn{2}{|c|}{ Jumlah Skor Maksimal } & \multicolumn{4}{|c|}{504} \\
\hline \multicolumn{2}{|c|}{ Nilai Rata-Rata } & $58.53 \%$ & $65.47 \%$ & $71.42 \%$ & $71.03 \%$ \\
\hline
\end{tabular}

Berdasarkan tabel di atas menunjukan bahwa penerapan strategi active learning tipe quiz team dari siklus I sampai siklus IV berjalan dengan baik. Hal ini ditunjukkan dengan adanya peningkatan nilai ratarata yang diperoleh siswa pada setiap tindakan dari penerapan strategi active learning tipe quiz team untuk menumbuhkan karakter rasa ingin tahu siswa dalam pembelajaran sejarah. Kenaikan nilai rata-rata siswa dari siklus I-IV lebih dari 50\% hal ini menunjukan bahwa strategi active learning tipe quiz team dapat menumbuhkan rasa ingin tahu siswa kelas X MIIA 3 SMA Kartika XIX-1 Bandung .

\section{SIMPULAN}

Berdasarkan hasil penelitian siklus kelas yang telah dilaksanakan dalam pembelajaran sejarah selama empat siklus ini, dapat ditarik kesimpulan bahwa dengan menggunakan strategi active learning tipe quiz team dapat menumbuhkan karakter rasa ingin tahu siswa kelas $\mathrm{X}$ MIIA 3 SMA Kartika XIX-1 Bandung. Hal tersebut dapat dibuktikan dengan meningkatnya nilai rata-rata karakter rasa ingin tahu siswa pada setiap siklusnya. Kemudian pada siklus keempat rasa ingin tahu siswa hanya mengalami sedikit penurunan sebesar $0.39 \%$ dari 
$71.42 \%$ pada siklus III kepada 71.03

$\%$ pada siklus IV. Hal ini menunjukan bahwa siswa sudah mengalami titik jenuh pada siklus keempat. Titik jenuh adalah titik berhenti dimana data tidak mengalami lagi perubahan (kenaikan atau penurunan) yang terlalu signifikan dari siklus sebelumnya yang mana hal itu menunjukan bahwa siklus yang dilakukan sudah cukup.

Berdasarkan hasil penelitian, peneliti mempunyai saran yang ingin peneliti sampaikan kepada berbagai pihak yang terlibat dengan penelitian ini. Diharapkan saran tersebut dapat membuat pembelajaran sejarah lebih baik dan efektif, sebagai upaya untuk memaksimalkan pencapaian tujuan pembelajaran sejarah yang dilaksanakan di sekolah.

Bagi guru, hasil penelitian ini dapat menjadi salah satu sumber informasi baru bagi guru dalam mengembangkan strategi pembelajaran, terutama dalam kegiatan belajar mengajar sejarah di kelas. Selain itu, penerapan strategi active learning tipe quiz team dapat dijadikan suatu alternatif solusi untuk menghadapi masalah pembelajaran yang ada di kelas.
Bagi siswa, siswa diharapkan dapat ikut berperan aktif dalam proses pembelajaran atau meningkatkan aktivitas dalam pembelajaran, selalu mengerjakan tugas-tugas yang diberikan guru dan meningkatkan usaha belajar sehingga dapat memperoleh hasil belajar yang optimal.

Bagi sekolah, penelitian ini dapat menjadi bahan pertimbangan bagi pihak sekolah untuk meningkatkan kualitas pembelajaran, khususnya dalam pembelajaran sejarah. Penelitian ini diharapkan dapat memberikan sumbangsih yang positif bagi perkembangan pembelajaran sejarah di sekolah.

\section{DAFTAR PUSTAKA}

Barnawi dan M. Arifin. (2012). Pembelajaran pendidikan karakter. Jogjakarta: Ar-Ruzz.

Djamarah. (2006). Strategi belajar mengajar. Jakarta: Rineka Cipta.

Hadiansyah, Yusep (2015). Penerapan model pembelajaran active learning tipe quiz team dengan keterampilan bertanya probing question untuk meningkatkan aktivitas belajar siswa dalam pembelajaran pkn. Skripsi UPI. Bandung: Tidak Diterbitkan. 
Hamdani. (2011). Strategi belajar mengajar. Bnadung: Pustaka Setia.

Hasan, S, H. (2008). Pengembangan kompetensi berpikir kritis dalam mata pelajaran sejarah. makalah pada seminar IKAHIMSI: Universitas Pendidikan Indonesia.

Komalasari, K. (2011). Pembelajaran kontekstual konsep dan aplikasi. Bandung: PT Refika Adiama.

Marno. dan M. Idris. (2011). Strategi dan metodologi pembelajaran. Jogjakarta: Ar - Ruzz Media Group.

Mulyasa. (2012). Manajemen pendidikan karakter. Jakarta: Bumi Aksara.

Mulyasa. (2014). Pengembangan dan implementasi kurikulum 2013. Bandung: Remaja Rosdakarya.

Nurani, Gustin (2015). Menumbuhkan karakter rasa ingin tahu siswa dalam pembelajaran sejarah melalui metode diskusi tipe ttw (think-talk-write). Skripsi UPI. Bandung: Tidak Diterbitkan.

Rohani, A. (2004). Pengelolaan pengajaran. Jakarta: Rineka Cipta.
Rosalia. (2005). Strategi belajar mengajar. Bandung: Pustaka Setia.

Sahla dan Teguh. (2012). Desain pembelajaran berbasis pendidikan karakter. Jakarta: Ar Rizz Media.

Samani, M dan Haryanto. (2011). Pendidikan karakter. Bandung: Remaja Rosdakarya.

Sanjaya, W. (2008). Strategi pembelajaran berorientasi standar proses pendidikan. Jakarta: Kencana Prenada Media Group.

Silberman. M. (2013). Pembelajaran aktif 101 strategi untuk mengajar secara aktif. Jakarta: Indeks.

Suyadi. (2013). Strategi pembelajaran pendidikan karakter. Bandung: Remaja Rosdakarya.

Warsono dan Hariyanto. (2014). Pembelajaran aktiv. Bandung: Remaja Rosda karya.

Zubaedi. (2012). Desain pendidikan karakter: konsepsi dan aplikasinya dalam lembaga pendidikan. Jakarta: Kencana Prenada Media Group. 